\title{
Risk Management Design in Retrofitting Existing Administrative Buildings to SustainableBuildings
}

Mahmoud Muhammad Atta Hussein a, Ali Fathy Eid b, Ahmed K. Abd El-Hameed c

A Master Student, Dept. of Architecture, Faculty of Engineering, Ain Shams University in EgyptCairo, Egypt

b Professor, Dept. of Architecture, Faculty of Engineering, Ain Shams University in EgyptCairo, Egypt

c Assistant Professor, Dept. of Architecture, Faculty of Engineering Ain Shams University inEgypt

\begin{abstract}
There is an energy crisis around the world according and presented by many types of research and solutions shown up to reduce energy using and material towards the environment, this research present the energy crisis problem towards the building's sector which using $40 \%$ of global energy in the world.
\end{abstract}

Research objective: in the energy retrofitting solution of an energy crisis around the world into energy using in the office buildings by leading and supporting the management into the design risk and shell the light of energy crisis case

The research theoretical method includes the research problem, aim, questions, the strategy of energy retrofitting, the definition of office buildings shell and core, the concept of energy retrofitting design, management of the energy projects, and the risk of energy retrofitting design. 
The practical method includes the case study in energy retrofitting programs around the world especially in developed countries, office buildings, and barriers, and challenges of energy retrofitting in developing countries the results will lead to creating a structure for supporting the managers by knowledge from experts in developing countries like Egypt.

\section{Keywords:}

- Energy retrofitting

- Office Buildings

- Risk assessment

- Energy Consumption

\section{INTRODUCTION}

The energy crisis problem has been around the world there is strategy has been created ( sustainable development 2030) this research is one of who supported the solution by building sector for energy reduction.

This research includes the problem about energy retrofitting in projects especially in the design phase for leading the project target successfully from low experience design worldwide and focusing on projects into the developing countries that are same factors which affect the project but into developing countries it been more even complex that's the main object of this research.

There are many barriers during the design phase that doesn't been over project manager responsibilities only, there is another parameter that joins into this operation and it starts with arisk of communication and skills between the whole project team parameters and factor.

This paper present the full method of energy retrofitting program includes the building definition, owner needs, definition of operating 
staff, the main Opportunities, the project design with full major data, the risk, case studies and finding from an expert.

All the previous results will lead for the structure will be added to risk design management into the energy project at the portfolio for been continues added more risk and upgraded what the same researches have been started or created in the same case or associated cases into energy management.

\subsection{Structure:}

This research includes 6 chapters starts with the definition in general of energy retrofitting strategies that will lead to the management then the risk, that process will be going into cases study after understanding the method and the risk of energy projects then the results will be reflected over the structure designed.

Chapter 1: energy retrofitting strategy (definition of all research statements and hypotheses) Chapter 2: Management of energy retrofitting (standard management includes energy projects)

Chapter 3: design risk of energy retrofitting (standard risk and gone throughout design phaseinto energy projects)

Chapter 4: a case study (which includes energy retrofitting program of office buildings andoffice buildings)

Chapter 5: results and finding ( comparing between the energy program and office buildings, added barriers of developing countries during energy projects, and created method structure of manage the energy design risk)

Chapter 6: Discussion and recommendation (feedback from an expert into method design structure and set the final reports about the research) 
Chapter One: Enerey

retrofiting Project Stratefies.

Chapter Two : Manage of the enerEy retrofitting

Chapter Three: : Manafe the risk of enerpy manipement

\section{Chapter Four: Case studies in} world developing countries

Chapter Five: Design

firamework structure risk desifn manipement

\section{Chapter Six: Discussion and} conclusion

\subsection{Tables:}

\section{Table 1 - energy retrofitting stages}

\begin{tabular}{l|l}
\hline Existing Commission buildings & $\begin{array}{l}25 \% \text { of energy-saving (counts over normal } \\
\text { building upgrading material and standard } \\
\text { energy saving). }\end{array}$ \\
\hline Standard retrofitting & $\begin{array}{l}\text { 25-40\% energy saving (the operating gone } \\
\text { deep into integrated design, specific } \\
\text { options. }\end{array}$ \\
\hline Deep energy retrofitting & $\begin{array}{l}45 \% \text { and even more for energy saving (the } \\
\text { operating is nearly standard retrofitting but } \\
\text { even higher into design high building } \\
\text { performance starts with (passive design) }\end{array}$ \\
\hline
\end{tabular}




\section{Table 2 - energy project opportunities}

\begin{tabular}{l|c}
\hline Building's owner & A healthy environment in the building \\
\hline Investment & Payback of project products \\
\hline Tenants & Barries against their needs \\
\hline Energy company services & Communication with owners and investments \\
\hline Society & Reducing energy for sustainable development \\
\hline
\end{tabular}

\section{Table 3 - Type of Risk into energy projects}

\begin{tabular}{c|c}
\hline External risk & $\begin{array}{c}\text { Includes the local environment }- \text { government } \\
\text { decisions }\end{array}$ \\
\hline Internal risk & $\begin{array}{c}\text { Counts over project staff to satisfied their } \\
\text { needs }\end{array}$ \\
\hline Risk factors & $\begin{array}{c}\text { The standard risk of energy projects } \\
\text { associated with each other }\end{array}$ \\
\hline
\end{tabular}

\subsection{Illustrations}

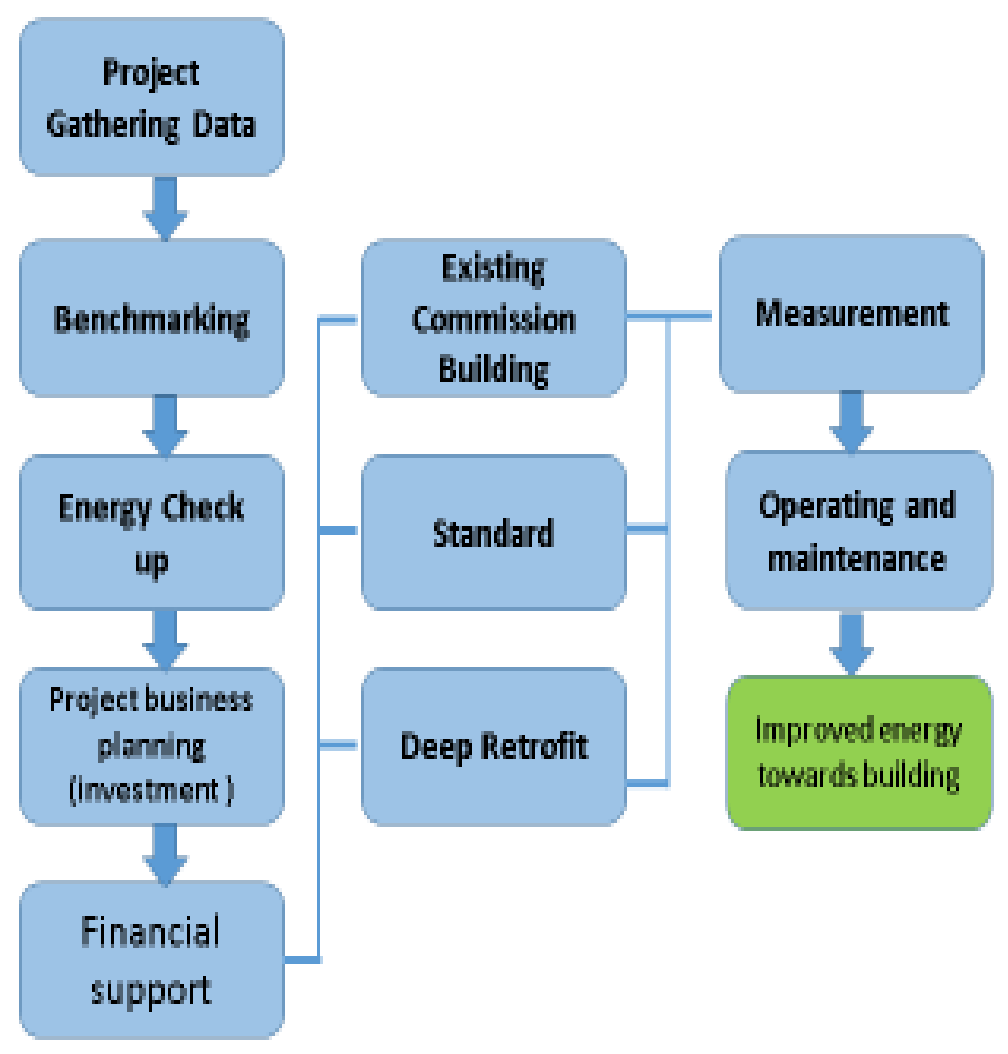

Figure 1: retrofitting office buildings 


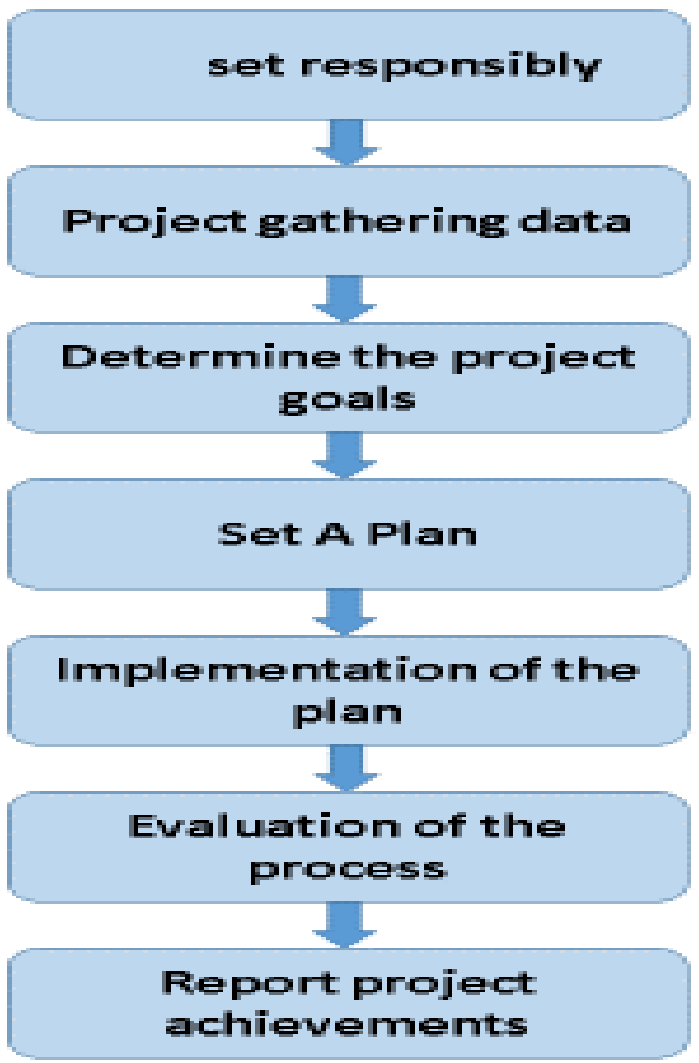

Figure 3: Management energy project (office buildings)

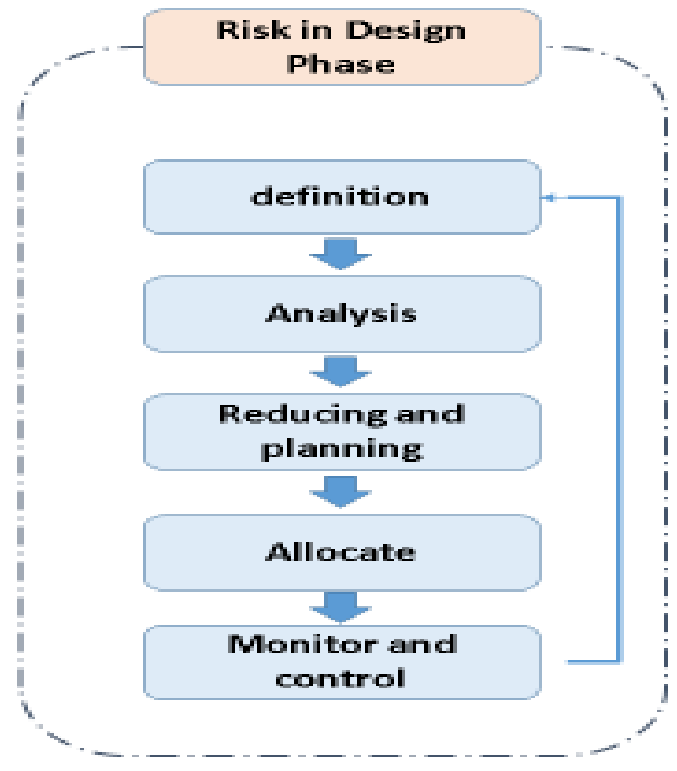

Figure 3: Risk Management energy project (office buildings) 


\section{MATERIALS AND METHODS:}

This research has been including two parts of methods

The theoretical method has been including the material which following:

It has been into three chapters research (Chapters 1,2 and 3 ) the material were into general observation into Egyptian environment into energy case, office building definition, energy strategy three types of energy retrofitting, the major process to success the energy projects, Opportunities and factors, methods, management, and risk management design.

\section{The practical method has been including the material which following:}

It has been into two chapters ( four and five) the worldwide energy program over energy retrofitting projects into commercial buildings and four office buildings and barriers into developing countries that will reflect over the results with the aim objective of research that will design a structured method to manage the design risk into energy project in case office buildings

\section{RESULTS AND DISCUSSION:}

After comparing the between office building and energy government program towards commercial building into the previous topic it has been structured a method which includes all design risk associated with each other by experts and their feedback for supporting it into developing countries such as Egypt by the policy of energy and local area government decisions and project staff operating.

It has been including feedback from experts which counts over government decisions towards EE projects and support by investment that will gain the trust of clients to make better decisions for their buildings. 


\section{CONCLUSION:}

There is many factors affect over green energy project internal and external all over project time that will lead for high cost and low quality, this kind of project one of the most complex project while definition the risk it will help to determine the value of the risk into the strategy and management which will reduce the risk and making the process more even easier for success project also there is future research will go in the same track which will be added the results into the portfolio and upgrading the strategy of the green energy projects.

To achieve the main goal to manage the design risk it has been updated by the following steps:

\section{Step 1: Building Definition, Strategy}

Gathering data such as building type, using, strategy, policy...etc.

\section{Step 2: project opportunities}

Looking forward to the chance to make the project been a reality.

\section{Step 3: Retrofitting method}

Understanding the major concepts of energy retrofitting projects within the payback period andbuilding payment equipment.

\section{Step 4: Energy management and risk design towards the retrofitting building}

It has been including the seven stages of managing the project but deeply steps into energy project kind to determine the major parameters to manage also within the design stage.

\section{Step 5: data collection towards energy project into the same case study}

Looking forwards to data and risk happened into some kind of your project and high lights therisk and how it has been treated, that will lead to developing your strategy within the design phase 


\section{References:}

\section{Master degree books}

- Albadry. S,2016 FEASIBILITY OF CONVERTING EXISTING RESIDENTIAL BUILDINGS TO NET-ZERO-ENERGY BUILDINGS IN EGYPT.

- M. ABDALLAHR.H,2015 Methodology Of Converting an Existing Buildings toSustainable Buildings.

- Mostafa, H, K,2016, EVALUATION OF GREEN BUILDING RATING SYSTEMS FOREGYPT

- Ahmed, R,2017 Energy Retrofit Decision Support Model for Existing Educational Buildings inEgypt

\section{Conference paper}

- Zhenjun Ma,2010 Existing building retrofits: Methodology and state-ofthe-art

- Patrick X. W. Zou Managing risks in complex building retrofit projects for energyand water efficiency 2016

- William. H RISK ASSESSMENT AND RETROFIT OF EXISTING BUILDINGS

- Lavanya, N. | Malarvizhi, T,2008 Risk analysis and management

- Retrofitting Public Building for Energy and Water efficiency: Guidelines, Financing,and Risks ( international conference paper)

- Abdallah, L, Shennawy, T, 2017 A METHODOLOGY FOR IMPROVING ENERGYPERFORMANCE IN EXISTING OFFICE BUILDINGS IN EGYPT: A CASE STUDY

\section{Website}

- www.wbdg.org

- https://valueandrisk.eefig.eu

Received: April 2021

Accepted: June 2021 